\title{
Test results of an external exhaust gas recirculation system of a Cooper Bessemer GMVH-8 engine-compressor
}

\author{
The paper presents results of research designed and constructed by the authors of external exhaust gas recircula- \\ tion Integral Engine-Compressor Cooper Bessemer GMVH-8. This system was used primarily to reduce emissions of \\ nitrogen oxides. \\ Key words: exhaust recirculation, reduce of $N O_{x}$ emission, $C N G$ engine-compressor, gas engine
}

\section{Wyniki badań układu zewnętrznej recyrkulacji spalin motosprężarki Cooper Bessemer GMVH-8}

W artykule przedstawiono wyniki badań zaprojektowanego i wykonanego przez autorów układu zewnętrznej recyrkulacji spalin motosprężarki Cooper Bessemer GMVH-8. Układ ten został zastosowany głównie w celu obniżenia poziomu emisji tlenków azotu.

Słowa kluczowe: recyrkulacja spalin, redukcja emisji $N O_{x}$, sprężarka silnika $C N G$, silnik gazowy

\section{Technical data of the Integral Engine-Com- pressor Cooper Bessemer GMVH-8}

Additional information:

- middle pressure of the end of compression stroke 23 bar

- maximum burning pressure 57 bar

- spread of pressure compression value between cylinders 5.25 bar

- exhaust temperature:

- middle value $370^{\circ} \mathrm{C}$

- maximum valve $400^{\circ} \mathrm{C}$

\section{Basic investigations of the pollution} of the engine-compressor exhaust

Despite the long-term operation of GMVH8 engine-compressor its technical state is very good. The modern Altronic ignition system (a result of the subsequent modernizations) was applied together with the gas supply system with a full monitoring of parameters in the different points (Fig. 2-9).

The results of the exhaust pollution measurements without this system is presented in Table 2. The measurements were performed at different engine-compressor loads with constant engine speed as recommended on the basis of longstanding experience.

\section{Design of the exhaust recirculation system.}

Fig. 10 depicts a basic element of the exhaust recirculation system - a valve to control the volumetric flow rate (3). An example of the whole system is presented in Fig. 11. It shows: an exhaust connecting pipe (1), the heat exchanger (2) applied in the exhaust recirculation system, the place of the control valve location (3), the place of the exhaust supply to the air intake system of the engine (4) as well as the exhaust and air lines $(5,6)$.

\section{Charakterystyka silnika motosprężarki GMVH 8}

Informacje dodatkowe:

- średnie ciśnienie końca sprężania (w stanie nagrzanym, przy pełnym obciążeniu i pełnej prędkości obrotowej) 23 bar

- maksymalne ciśnienie spalania ........................... 57 bar

- dopuszczalny rozrzut ciśnień między cylindrami 5,25 bar

- temperatura spalin na wylocie:

- średnia $370^{\circ} \mathrm{C}$

- maksymalna $400^{\circ} \mathrm{C}$

\section{Wstępne badania emisji zanieczyszczeń spalin} silnika motosprężarki

Mimo długoletniej eksploatacji motosprężarek GMVH8 są one utrzymywane w bardzo dobrym stanie technicznym. W wyniku kolejnej modernizacji zastosowano nowoczesny układ zapłonowy i zasilania gazowego produkcji firmy ALTRONIC $\mathrm{z}$ pełnym monitoringiem parametrów $\mathrm{w}$ istotnych węzłach (rys. 2-9).W tabeli 2 przedstawiono pomiary emisji zanieczyszczeń spalin silnika motosprężarki, przed zastosowaniem układu recyrkulacji spalin.

Pomiary prowadzono przy różnych obciążeniach motosprężarki jednak przy stałej prędkości obrotowej, zalecanej na podstawie wieloletniego doświadczenia.

\section{Projekt układu recyrkulacji spalin}

Na rysunku 10 przedstawiono podstawowy element układu recyrkulacji spalin - zawór do sterowania natężeniem przepływu (3). Na rys. 11 przedstawiono schemat całego układu z króćcem poboru spalin (1), wymiennikiem ciepła spalin (2) stosowanych w obiegu recyrkulacji, miejsce usytuowania zaworu sterującego (3), miejsca wprowadzenia 
Table 1. Technical data of the engine of Integral Engine-Compressor Cooper Bessemer GMVH-8 Tabela 1. Dane techniczne silnika motosprężarki GMVH 8

\begin{tabular}{|c|c|c|}
\hline Lp. & Parameter/parametr & Value/wartość \\
\hline 1. & Manufacturer/produkcja & Cooper Bessemer Francja \\
\hline 2. & Type/typ & GMVH 8 \\
\hline 3. & Ignition/working cycle/zaplon/cykl pracy & $\begin{array}{l}\text { Spark ignition/two stroke, turbocharging/ } \\
\text { iskrowy/dwusuwowy, doładowany z chtodzeniem tadunku }\end{array}$ \\
\hline 4. & Design/konstrukcja & Vertical, V-type, liquid cooling/pionowy w układzie V, chtodzony ciecza \\
\hline 5. & Numer of cylinders/liczba cylindrów & 8 \\
\hline 6. & Diameter of a cylinder/średnica cylindra & $355.6 \mathrm{~mm}$ \\
\hline 7. & Stroke of a piston/skok ttoka & $355.6 \mathrm{~mm}$ \\
\hline 8. & Fuel/paliwo & Natural gas (metan) E/gaz ziemny wysokometanowy E (GZ-50) \\
\hline 9. & Ignition system/uklad zaplonowy & $\begin{array}{l}\text { High energetic, Altronic, twin spark pro cylinder/ } \\
\text { wysokoenergetyczny Altronic, dwie świece zapłonowe na każdy cylinder silnika }\end{array}$ \\
\hline 10. & Supply system/uklad zasilania & $\begin{array}{l}\text { Gas delivery to the cylinder through the valve under pressure } 3.50-3.85 \text { bar } \\
\text { Valve opening } 125 \text { - before TDC/wdmuch gazu ziemnego bezpośrednio do cylindra silni- } \\
\text { ka, sterowany zaworem grzybkowym uruchomianym mechanizmem krzywkowym. } \\
\text { Ciśnienie wdmuchu } 3,50-3,85 \text { bar. Otwarcie zaworu } 125^{\circ} \text { OWK przed GMP }\end{array}$ \\
\hline 11. & Firing order/kolejność zapłonów & $\begin{array}{c}1 \mathrm{~L}-1 \mathrm{P}-4 \mathrm{~L}-4 \mathrm{P}-2 \mathrm{~L}-2 \mathrm{P}-3 \mathrm{~L}-3 \mathrm{P} \\
\text { (L- left or } \mathrm{R} \text { - right side)/(L-lewa, P-prawa strona silnika) cylindry } \\
1 L \text { i } 4 \mathrm{~L}, 1 \mathrm{P} \text { i } 4 P, 2 \mathrm{~L} \text { i } 3 \mathrm{~L}, 2 \mathrm{P} \text { i } 3 \text { P zapalaja jednocześnie }\end{array}$ \\
\hline 12. & Nominal rpm/prędkość obrotowa, znamionowa & $330 \mathrm{rpm}$ \\
\hline 13. & Nominal power/moc znamionowa & $1170 \mathrm{~kW}$ \\
\hline 14. & Nominal torque/moment obrotowy znamionowy & $33855 \mathrm{~N} \cdot \mathrm{m}$ \\
\hline 15. & Power control/regulacja mocy silnika & $\begin{array}{c}\text { Quantity governing/regulacja ilościowa; regulacja napetnienia cylindrów silnika poprzez } \\
\text { sterowanie układu obejściowego spalin wokót turbosprężarki }\end{array}$ \\
\hline
\end{tabular}

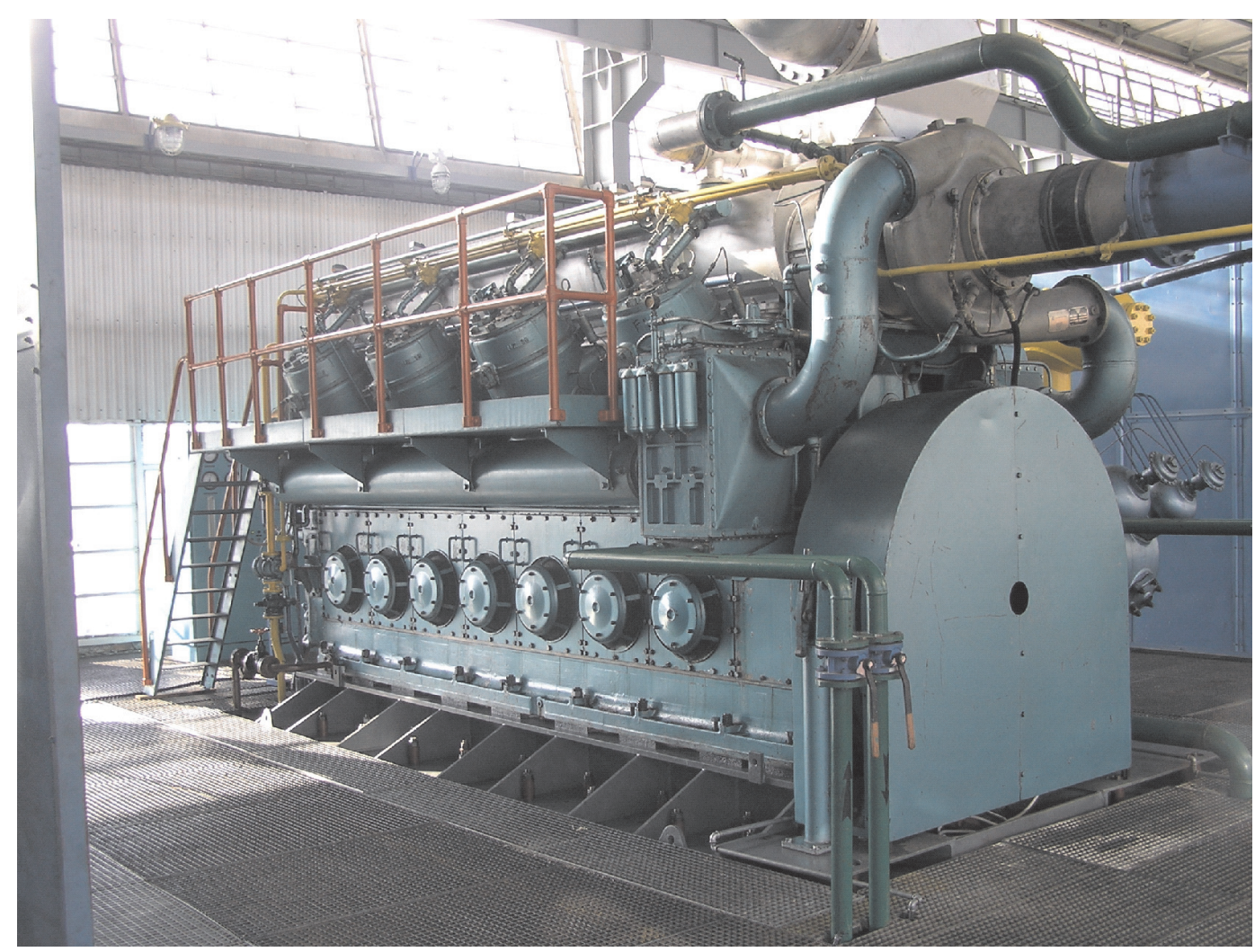

Fig. 1. General view of the Integral Engine-Compressor Cooper Bessemer GMVH-8.

Rys. 1. Widok ogólny motosprężarki Cooper Bessemer GMVH-8. 


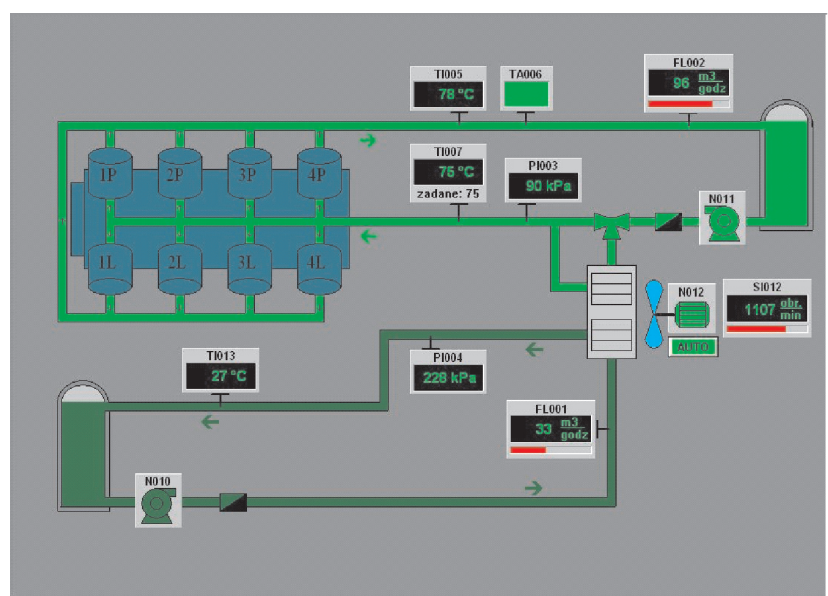

Fig. 2. Monitoring of the cooling parameters Integral Engine-Compressor Rys. 2. Monitorowanie parametrów chłodzenia motosprężarki

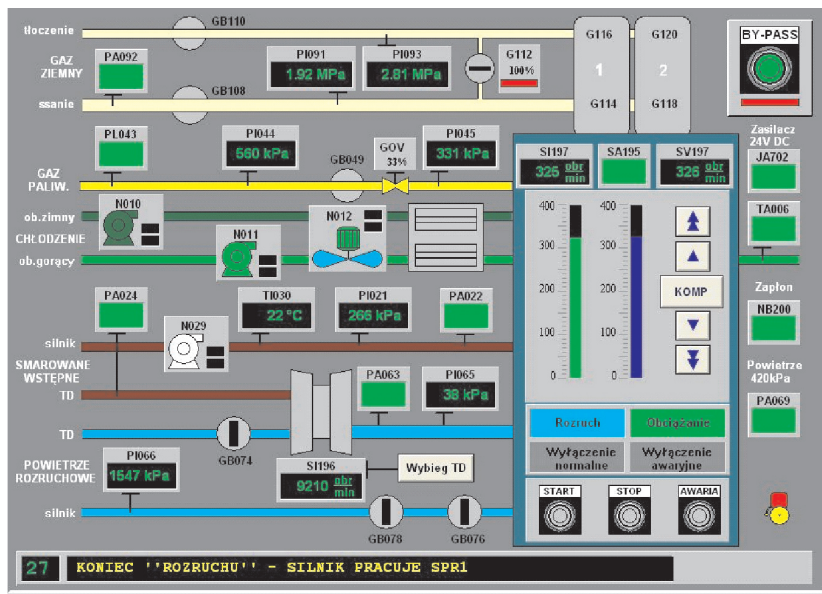

Fig. 4. Monitoring of the general parameters Integral Engine-Compressor Rys. 4. Monitorowanie ogólnych parametrów motosprężarki

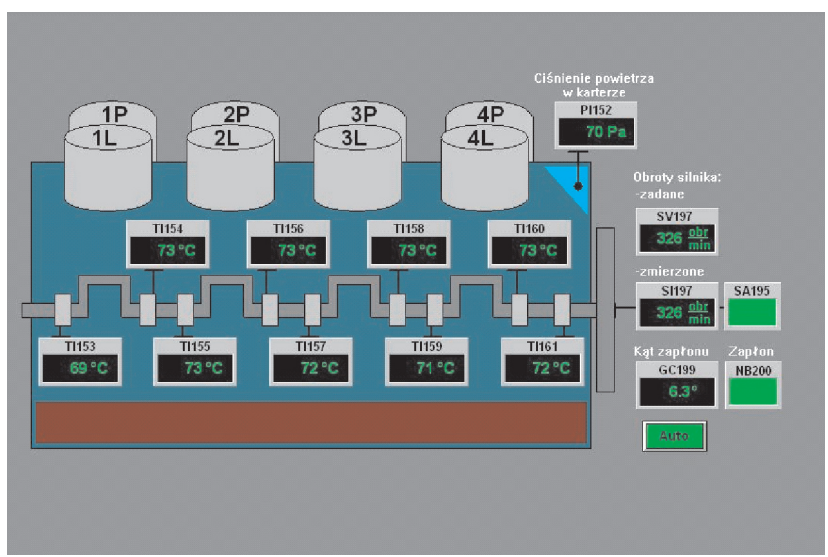

Fig. 6. Monitoring of the crank system parameters Integral Engine-Compressor

Rys. 6. Monitorowanie parametrów ukladu korbowego motosprężarki

The valve for hand steering of the exhaust flow rate added to the air intake system was constructed on the basis of calculations. To provide approximately linear flow of the exhaust gases the valve enabling exhaust flow rate control in the range of 0 to about $30 \%$ (in fresh mixture) was used.

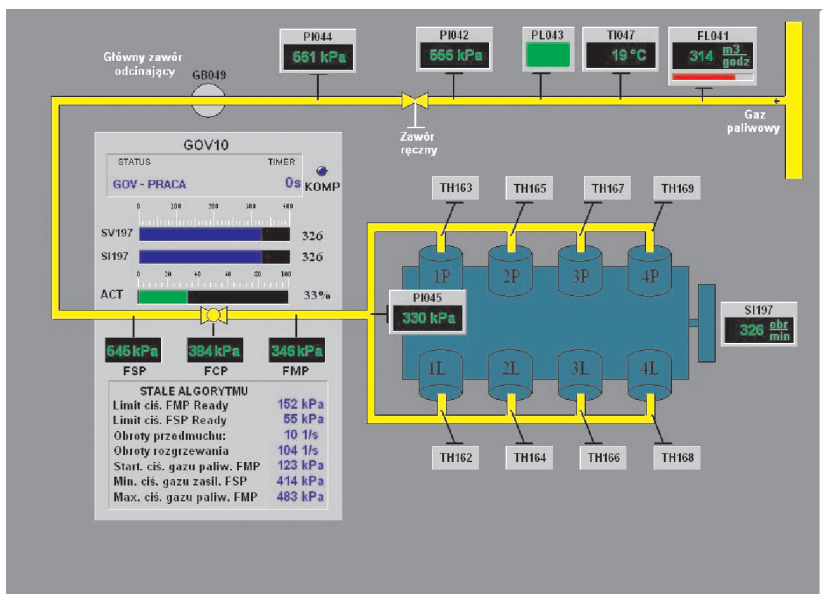

Fig. 3. Monitoring of the gas sypply parameters Integral Engine-Compressor

Rys. 3. Monitorowanie parametrów ukladu zasilania gazem motosprężarki

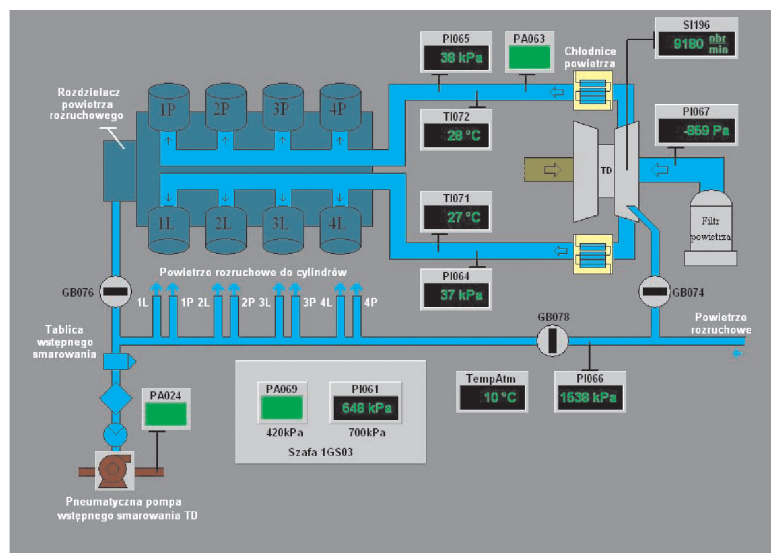

Fig. 5. Monitoring of the starting parameters Integral Engine-Compressor Rys. 5. Monitorowanie parametrów układu rozruchu motosprężarki

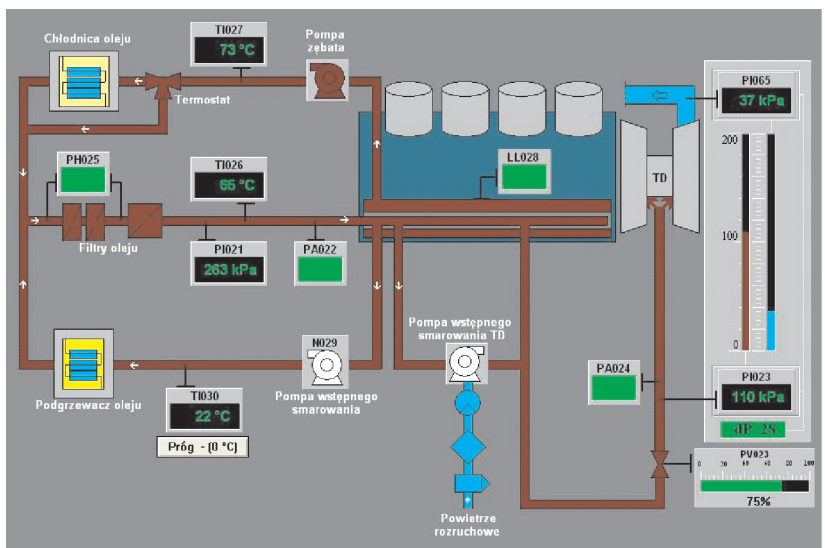

Fig. 7. Monitoring of the lubrication system parameters Integral EngineCompressor

Rys. 7. Monitorowanie parametrów układu smarowania motosprężarki

spalin do układu dolotowego powietrza do silnika (4) oraz przewody spalinowe (5) i powietrzne (6).

Na podstawie przeprowadzonych obliczeń skonstruowano i wykonano zawór do ręcznego sterowania natężeniem przepływu spalin dostarczanych do układu dolotu powietrza 


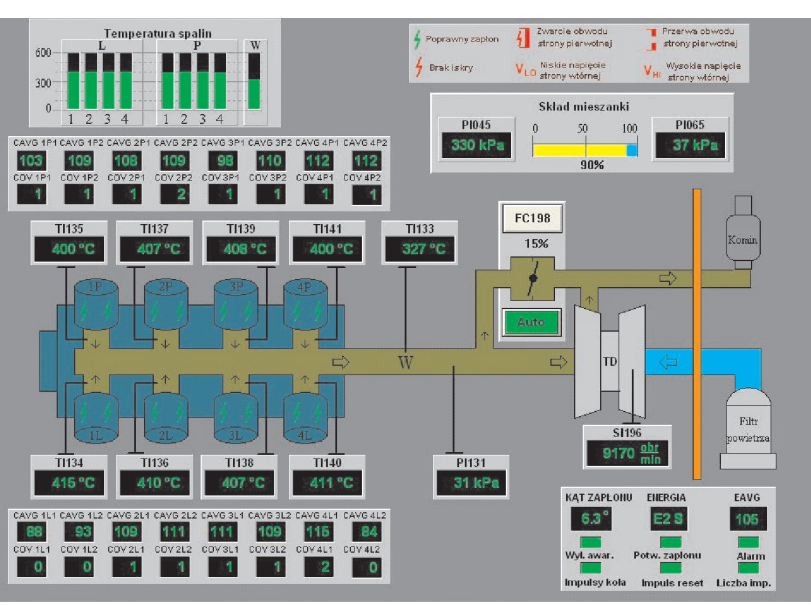

Fig. 8. Monitoring of the exhaust system parameters Integral EngineCompressor

Rys. 8. Monitorowanie parametrów układu wylotu spalin motosprężarki

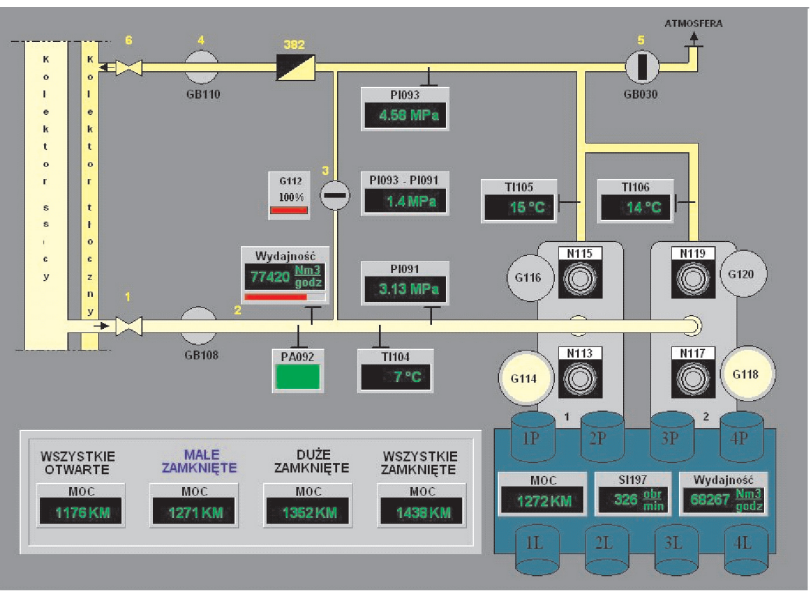

Fig. 9. Monitoring of the gas compresor parameters

Rys. 9. Monitorowanie parametrów sprężarek gazu przesyłowego

Table 2. Initial tests of the engine exhaust emission of Integral Engine-Compressor

Tabela 2. Badania początkowe emisji zanieczyszczeń spalin silnika motosprężarki

\begin{tabular}{|c|c|c|c|c|c|}
\hline Lp. & $\begin{array}{ll}\text { Parametr } & \text { Warunki pracy silnika } \\
\end{array}$ & $\begin{array}{c}\mathrm{N}_{\mathrm{e}}=1317 \mathrm{KM} \\
\mathrm{n}_{\mathrm{s}}=330 \mathrm{obr} / \mathrm{min}\end{array}$ & $\begin{array}{c}\mathrm{N}_{\mathrm{e}}=1435 \mathrm{KM} \\
\mathrm{n}_{\mathrm{s}}=330 \mathrm{obr} / \mathrm{min}\end{array}$ & $\begin{array}{c}\mathrm{N}_{\mathrm{e}}=1550 \mathrm{KM} \\
\mathrm{n}_{\mathrm{s}}=330 \mathrm{obr} / \mathrm{min}\end{array}$ & $\begin{array}{c}\mathrm{N}_{\mathrm{e}}=1640 \mathrm{KM} \\
\mathrm{n}_{\mathrm{s}}=325 \mathrm{obr} / \mathrm{min}\end{array}$ \\
\hline 1. & Stężenie $\mathrm{O}_{2}[\%$ obj.] & 14,9 & 16,0 & 14,0 & 15,5 \\
\hline 2. & Stężenie $\mathrm{CO}_{2}[\%$ obj. $]$ & 3,4 & 2,8 & 3,9 & 3,0 \\
\hline 3. & Stężenie CO [ppm obj.] & 129 & 88 & 343 & 86 \\
\hline 4. & Stężenie NO [ppm obj.] & 466 & 392 & 681 & 599 \\
\hline 5. & Współczynnik nadmiaru powietrza $\lambda[-]$ & 3,44 & 4,20 & 3,00 & 3,82 \\
\hline 6. & Ciśnienie $\mathrm{P}_{\mathrm{D}}[\mathrm{Pa}]$ & 163 & 196 & 198 & 212 \\
\hline 7. & Temperatura powietrza do spalania $\mathrm{T}_{\mathrm{P}}\left[{ }^{\circ} \mathrm{C}\right]$ & 4,5 & 4,6 & 5,2 & 4,9 \\
\hline 8. & Temperatura spalin $\mathrm{T}_{\mathrm{S}}\left[{ }^{\circ} \mathrm{C}\right]$ & 341 & 341 & 348 & 348 \\
\hline 9. & Temperatura punktu rosy $\mathrm{T}_{\mathrm{ROS}}\left[{ }^{\circ} \mathrm{C}\right]$ & 42 & 39 & 44 & 41 \\
\hline 10. & Strata wylotowa $\mathrm{Q}_{\mathrm{A}}[\%]$ & 39,4 & 47,4 & 35,5 & 44,3 \\
\hline \multicolumn{6}{|c|}{ Wyniki pomiarów $\mathrm{CO}$ i NO zredukowane dla $0 \%$ obj. $\mathrm{O}_{2}$} \\
\hline 11. & Stężenie CO [ppm obj.] & 443 & 369 & 1029 & 328 \\
\hline 12. & Emisja CO $\left[\mathrm{mg} / \mathrm{m}^{3}\right]$ & 553 & 461 & 1286 & 410 \\
\hline 13. & Stężenie NO [ppm obj.] & 1603 & 1646 & 2043 & 2288 \\
\hline 14. & Emisja NO $\left[\mathrm{mg} / \mathrm{m}^{3}\right]$ & 3291 & 3380 & 4195 & 4698 \\
\hline \multicolumn{6}{|c|}{ Wyniki pomiarów CO i NO zredukowane dla $3 \%$ obj. $\mathrm{O}_{2}$} \\
\hline 15. & Stężenie CO [ppm obj.] & 380 & 317 & 881 & 281 \\
\hline 16. & Emisja $\mathrm{CO}\left[\mathrm{mg} / \mathrm{m}^{3}\right]$ & 475 & 396 & 1101 & 351 \\
\hline 17. & Stężenie NO [ppm obj.] & 1374 & 1411 & 1750 & 1959 \\
\hline 18. & Emisja NO $\left[\mathrm{mg} / \mathrm{m}^{3}\right]$ & 2823 & 2899 & 3596 & 6406 \\
\hline
\end{tabular}

The basic problem was the high temperature of the exhaust gases entering the connecting pipe (1) from the outlet, which in the whole range of an engine load was $300^{\circ} \mathrm{C}$ or higher.

The maximum temperature of air delivered to the engine should not exceed $45^{\circ} \mathrm{C}$, even in summer when the ambient temperature achieves $35-38^{\circ} \mathrm{C}$.

So the effective cooling system of the exhaust gases should be constructed (2). The system was made of the set of copper tubes panels cooled by water in an open cycle. The exhaust gases flow through the panels so they have the direct contact with do silnika. W celu zapewnienia przepływu zbliżonego do liniowego zastosowano układ zaworu grzybkowego o takiej charakterystyce aby była możliwość sterowania przepływem w zakresie od 0 do około $30 \%$ udziału spalin w świeżym ładunku. Podstawowy problem stanowiła wysoka temperatura spalin pobieranych $\mathrm{z}$ układu wylotowego króćcem (1), która w całym zakresie obciążeń silnika motosprężarki utrzymywała się na poziomie powyżej $300^{\circ} \mathrm{C}$.

Maksymalna temperatura powietrza na dolocie do silnika nie może przekroczyć $45^{\circ} \mathrm{C}$, przy czym należy 
the tubes surface. In this way the exhaust temperature is reduced from $300^{\circ} \mathrm{C}$ to $70^{\circ} \mathrm{C}$. Such cooled exhaust gases mixed with fresh air reach the temperature below $30^{\circ} \mathrm{C}$.

\section{Investigation of the GMVH8 engine- compressor, optimi- zation of parameters}

The measurements were performed with different engine loads, constant ignition advance angle and the constant air/gas pressures ratio.

Determination of the the influence of the exhaust recirculation degree on the effective engine-compressor parameters was the next stage of the research. After achivinig a thermal equilibrium of the engine the amount of exhaust gases in a fresh mixture was gradually increased and the following parameters were registred:

- $\mathrm{NO}_{\mathrm{x}}$ concentration and emission

- $\mathrm{CO}$ concentration and emission

- $\mathrm{CO}_{2}$ concentration and emission

- THC concentration and emission

- the temperature of exhaust at the intake to turbo-charger

- the pressure of exhaust at the intake to turbo-charger

- the temperature of an intake mixture at inlet and outlet of the air cooler

- the mixture pressure at inlet and outlet of the turbocharger

- the temperature of exhaust before and after the heat exchanger

- the load of engine working with an automatic control of ignition advance angle and the fuel mixture composition

Degree of exhaust recirculation was calculated with the following formula:

$$
\mathrm{X}_{\mathrm{EGR}}=\frac{\mathrm{CO}_{2 \mathrm{~d}}}{\mathrm{CO}_{2 \mathrm{w}}-\mathrm{CO}_{2 \mathrm{~d}}} \cdot 100 \%
$$

where: $\mathrm{CO}_{2 \mathrm{w}}[\%]$ - concentration of carbon dioxide in the outlet manifold of engine, $\mathrm{CO}_{2 \mathrm{~d}}[\%]$ - concentration of carbon dioxide in the intake manifold of engine (before the mixture enters to the cylinders).

\section{Results}

Figures 12, 13 and 14 depict the dependence of $\mathrm{NO}_{\mathrm{x}}, \mathrm{CO}$ and $\mathrm{CO}_{2}$ emissions versus exhaust recirculation degree.

High content of oxygen in exhaust comes from cylinder loop scavenging (as in a two stroke engine). podkreślić, że taka temperatura musi być utrzymana również w upalne lata gdy temperatura otoczenia osiąga wartość $35-38^{\circ} \mathrm{C}$. Wobec powyższego należało skonstruować wydajny układ chłodzenia spalin pobieranych do recyrkulacji (2). Układ ten wykonano z zestawu paneli rurek miedzianych, przez które przepływała woda bieżąca pobierana z sieci wodociągowej (układ otwarty) a spaliny pod własnym ciśnieniem prowadzono tunelem (obudową rurek), tak aby miały one bezpośredni kontakt z powierzchnią rurek w panelach. W ten sposób udało się obniżyć temperaturę spalin z poziomu około $300^{\circ} \mathrm{C}$ do wartości poniżej $70^{\circ} \mathrm{C}$. Po wymieszaniu ochłodzonych spalin ze świeżym powietrzem, temperatura powietrza i spalin doprowadzanych do układu dolotowego utrzymywała się na poziomie poniżej $30^{\circ} \mathrm{C}$.

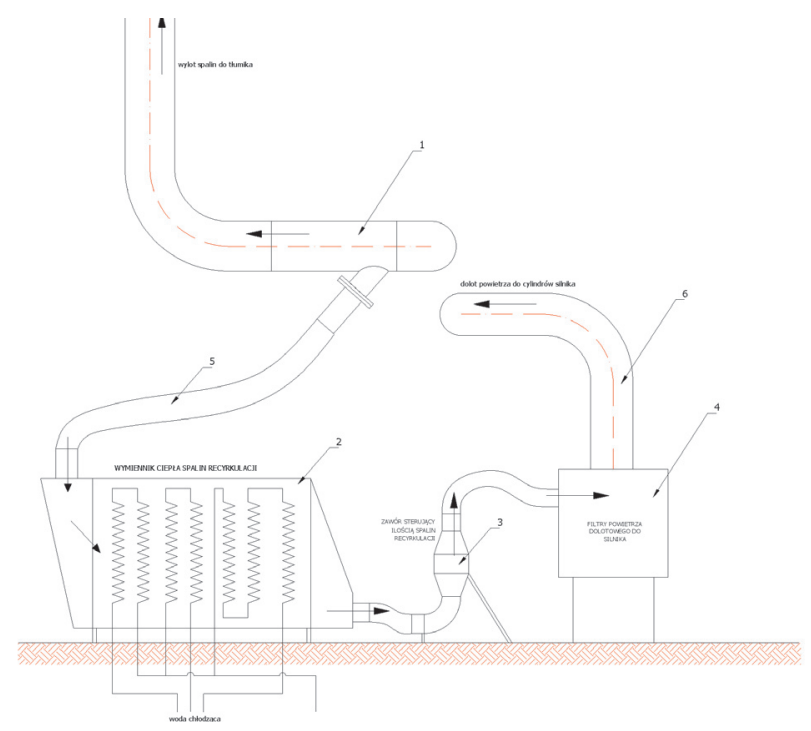

Fig. 11. Scheme of exhaust gas recirculation of Integral Engine-Compressor GMVH-8

Rys. 11. Schemat układu recyrkulacji motosprężarki GMVH 8

\section{Badania motosprężarki GMVH8, optymalizacja parametrów}

Pomiary prowadzono przy różnych obciążeniach silnika, przy stałym kącie wyprzedzenia zapłonu oraz przy stałym stosunku ciśnienia, pod którym doprowadzono gaz i powietrze (turbodoładowanie) a więc przy stałym składzie mieszanki, dla różnych wartości stopnia recyrkulacji spalin.

Kolejnym etapem było określenie wpływu stopnia recyrkulacji spalin na parametry efektywne silnika motosprężarki.

Po osiągnięciu roboczego stanu cieplnego silnika stopniowo zwiększano udział recyrkulowanych spalin w świeżym ładunku doprowadzanym do cylindrów przy równoczesnej rejestracji następujących parametrów pracy silnika:

- stężenia i emisji $\mathrm{NO}_{\mathrm{x}}$

- stężenia i emisji CO

- stężenia i emisji $\mathrm{CO}_{2}$ 
Analysis of Fig. 16 depicting the influence of recirculation degree on the engine power enables determination exhaust gases content in the mixture above which the significant $\mathrm{n}_{\mathrm{s}}=327 \mathrm{obr} / \mathrm{min}=$ const power loss is observed. In case of the applicated loadings the $\mathrm{X}_{\mathrm{EGR} 1}$ should be within the range of $12-13 \%$.

Figures 12, 13 and 14 show that minimal emission of $\mathrm{NO}_{\mathrm{x}}$ (reduction by $33 \%$ ) can be achieved for $\mathrm{X}_{\mathrm{EGR}}=15 \%$, nevertheless $9 \%$ loss of power occures. Besides in this case $\mathrm{CO}$ emission increases by about $10 \%$ and $\mathrm{CO}_{2}$ emission remains constant.

Analysis of Figs 17, 18, 19 and 20 verifies the above conclusions. It also confirms that such parameters like the effective power $\mathrm{N}_{\mathrm{e}}, \mathrm{G}_{\mathrm{e}}$ and $\mathrm{g}_{\mathrm{e}}$ describing general engine efficiency and the degree of recirculation $X_{\mathrm{EGR}}=15 \%$ can be considered as optimal values for such emission reduction.

\section{Conclusions}

Application of the exhaust recirculation system reduces the $\mathrm{NO}_{x}$ emission by about $33 \%$. Engine-compressor works in a very narrow range of loads and engine speeds 325-330 rpm which eliminates necessity of using of a very complicated exhaust gases dosing system.

1.Application of the exhaust recirculation system enables the significant $\mathrm{NO}_{\mathrm{x}}$ emission reduction.

2 . The system should be chosen thoroughly - the maximum $\mathrm{X}_{\mathrm{EGR}}$ coefficient should not exceed $15 \%$ what corresponds to about $28 \%$ of exhaust gases content in a fresh mixture.

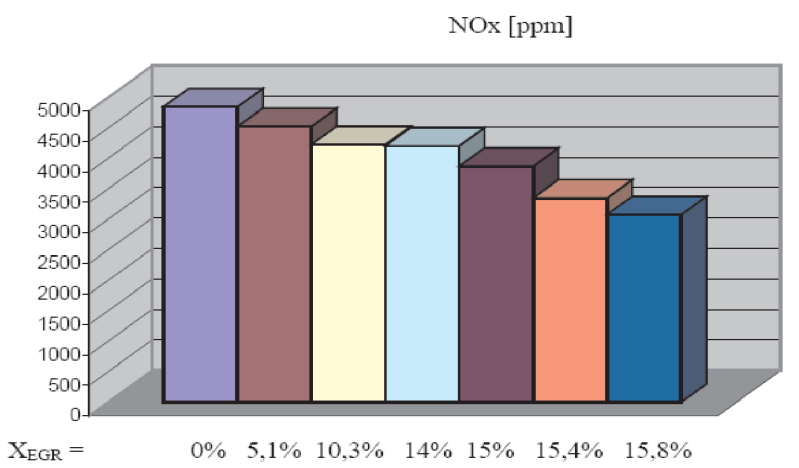

Fig. 12. Influence of EGR on the concentration of nitrogen oxides Rys. 12. Wplyw stopnia recyrkulacji spalin na stężenie tlenków azotu

$$
\mathrm{CO}_{2}[\%]
$$

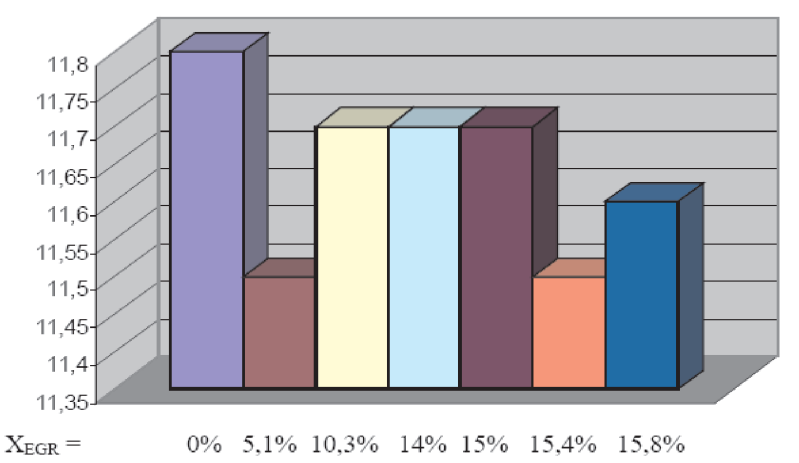

Fig. 14. Influence of EGR on the concentration of carbon dioxide Rys. 14. Wplyw stopnia recyrkulacji spalin na stężenie dwutlenku węgla
- stężenia i emisji THC

- temperatury spalin przed turbosprężarką

- ciśnienia spalin przed turbosprężarką

- temperatury zasysanego ladunku przed i za chłodnicą powietrza

- ciśnienia ładunku przed i za turbosprężarką

- temperatury spalin przed i za wymiennikiem ciepła

- obciążenia silnika przy automatycznej regulacji kąta wyprzedzenia zapłonu i składu mieszanki paliwowo-powietrznej.

Stopień recyrkulacji spalin $\mathrm{X}_{\mathrm{EGR}}$ określono metodą porównania stężenia $\mathrm{CO}_{2} \mathrm{w}$ układzie dolotowym i wylotowym (1),

gdzie: $\mathrm{CO}_{2 \mathrm{w}}[\%]$ - stężenie dwutlenku węgla w układzie wylotowym silnika, $\mathrm{CO}_{2 \mathrm{~d}}[\%]$ - stężenie dwutlenku węgla w układzie dolotowym silnika (przed wejściem do cylindra).

\section{Wyniki badań}

Na rys. 12, 13 i 14 przedstawiono na wykresach słupkowych zależność emisji $\mathrm{NO}_{x}, \mathrm{CO}$ i $\mathrm{CO}_{2}$ od stopnia recyrkulacji spalin. Na uwagę zasługuje duża zawartość tlenu w spalinach pochodząca z powietrza płuczącego cylindry, zjawiska charakterystycznego dla silników dwusuwowych doładowanych.

Analizując wykres na rys. 16 obrazujący zależność wartości mocy silnika od stopnia recyrkulacji możemy określić granicę, przy której dalsze dodawanie spalin do świeżego ładunku powoduje wyraźną utratę mocy. W przypadku

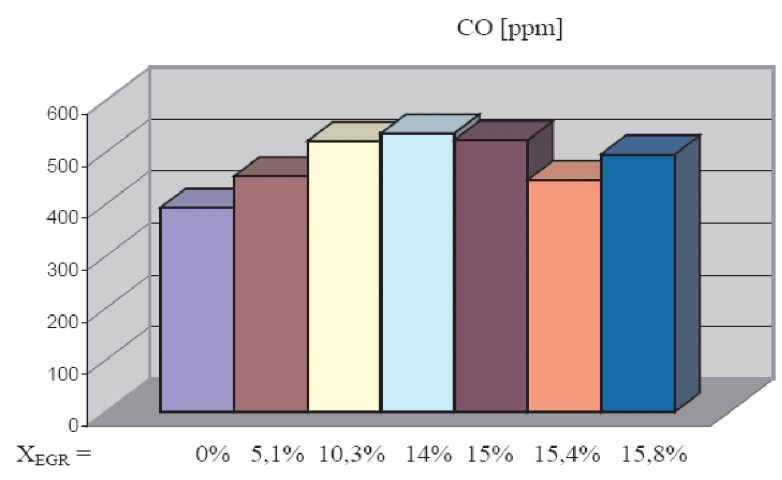

Fig. 13. Influence of EGR on the concentration of carbon monoxide Rys. 13. Wpływ stopnia recyrkulacji spalin na stężenie tlenku węla

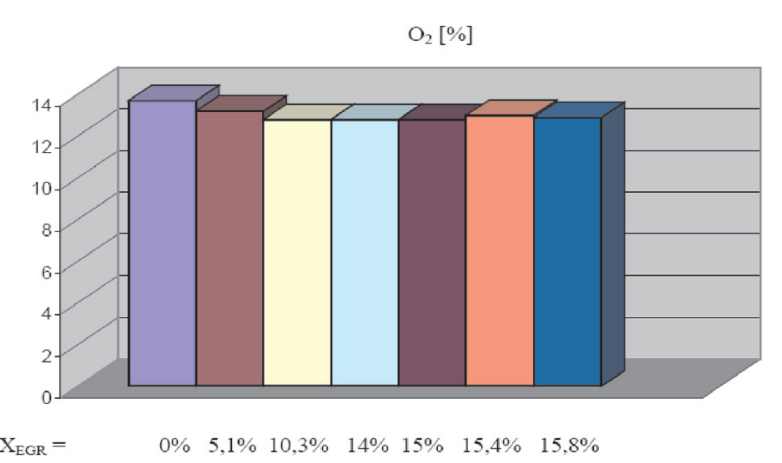

Fig. 15. Influence of EGR on the concentration of oxygen

Rys. 15. Wplyw stopnia recyrkulacji spalin na stężenie tlenu 
$\mathrm{Ne}[\mathrm{KM}]$

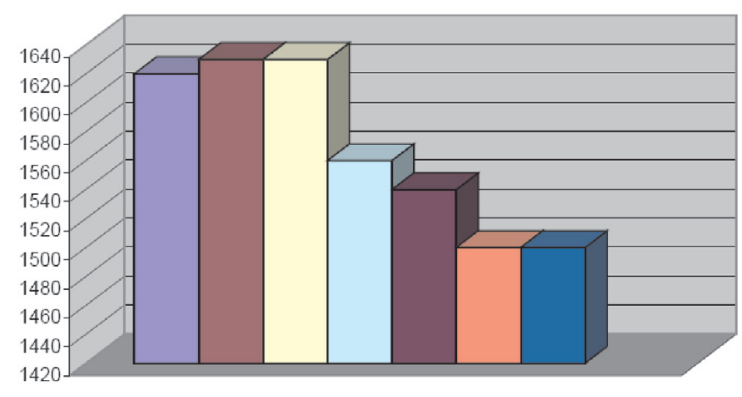

$\mathrm{X}_{\mathrm{EGR}}=$

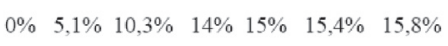

Fig. 16. The effect of exhaust gas recirculation to the effective power of Integral Engine-Compressor

Rys. 16. Wphyw stopnia recyrkulacji spalin na moc efektywna motosprężarki

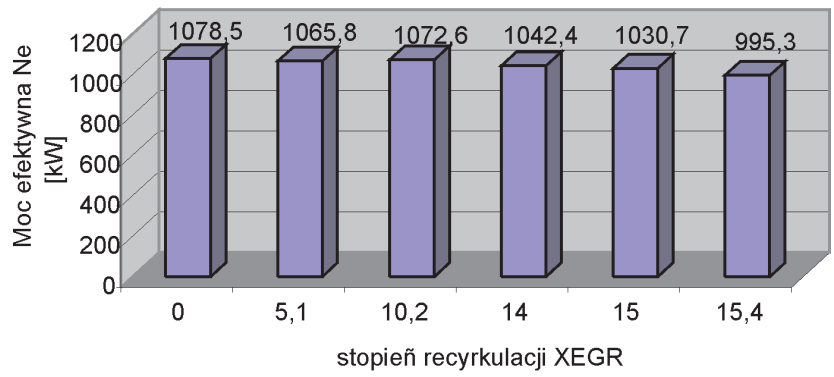

Fig. 17. Influence of EGR on engine load

Rys. 17. Wplyw stopnia recyrkulacji spalin na obciażenie silnika

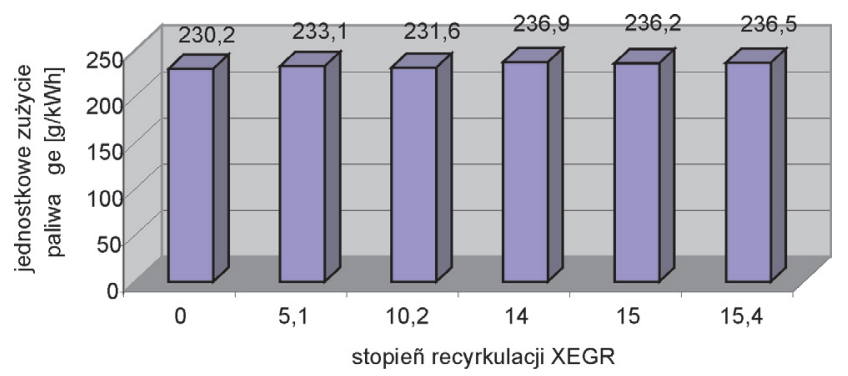

Fig. 19. Influence of EGR on the specific fuel consumption Rys. 19. Wplyw stopnia recyrkulacji spalin na jednostkowe zuzycie paliwa

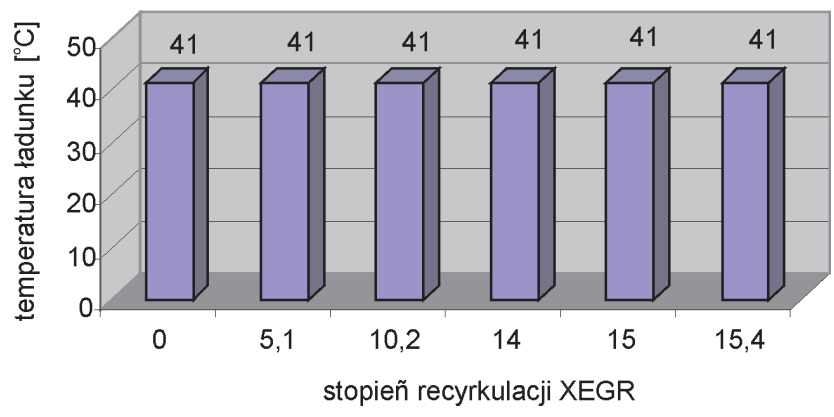

Fig. 21. Influence of EGR on the charge temperature at the inlet to the cylinders

Rys. 21. Wplyw stopnia recyrkulacji spalin na temp. ładunku na wlocie do cylindrów występujących tu obciążeń granicę należałoby określić na poziomie $\mathrm{X}_{\mathrm{EGR}}=12-13 \%$.

Analizując wykresy rys. 12, 13 i 14 pod kątem granicy najmniejszej emisji $\mathrm{NO}_{x}, \mathrm{CO}$ i $\mathrm{CO}_{2}$ widzimy, że optimum leży bliżej $\mathrm{X}_{\mathrm{EGR}}=15 \%$ ale wówczas musimy liczyć się z około $9 \%$ spadkiem mocy. W tym przypadku uzyskujemy jednak ponad $33 \%$ obniżenie emisji $\mathrm{NO}_{\mathrm{x}}$ przy około $10 \%$ wzroście emisji CO i praktycznie stałym poziomie emisji $\mathrm{CO}_{2}$.

Weryfikację powyższych wniosków daje nam analiza wykresów rys. 17, 18, 19 i 20. Potwierdza się, że z uwagi na takie parametry jak moc efektywna $\mathrm{N}_{\mathrm{e}}$, godzinowe $\mathrm{G}_{\mathrm{e}}$ i jednostkowe zużycie paliwa $g_{\mathrm{e}}$ określające sprawność ogólną silnika wartość stopnia recyrkulacji rzędu $\mathrm{X}_{\mathrm{EGR}}=15 \%$ może być przyjęta jako wartość optymalna ze względu na rozpatrywane kryteria.

Notowany wzrost wartości temperatury spalin przy $\mathrm{X}_{\mathrm{EGR}}=$ $=15 \%$ rzędu $12^{\circ} \mathrm{C}$ stanowi niecałe $4 \%$ wartości wyjściowej przy $\mathrm{X}_{\mathrm{EGR}}=0$, co przy istniejącej możliwości zwiększenia skuteczności układu chłodzenia spalin nie stanowi problemu.

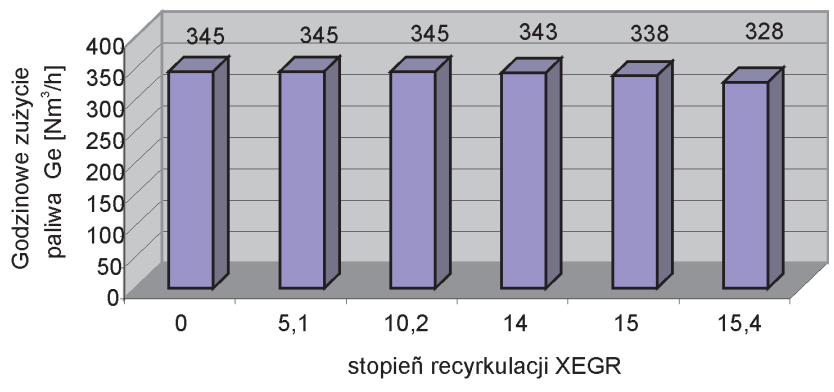

Fig. 18. Influence of EGR on the mass fuel consumption Rys. 18. Wplyw stopnia recyrkulacji spalin na godzinowe zużcie paliwa

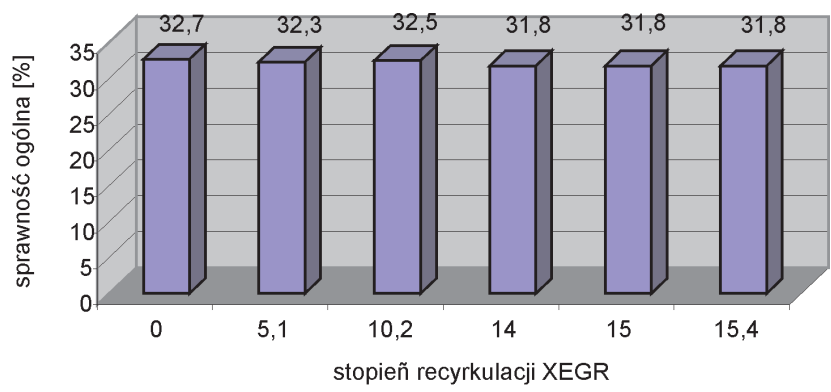

Fig. 20. Influence of EGR on the overall efficiency of the engine of Integral Engine-Compressor

Rys. 20. Wpływ stopnia recyrkulacji spalin na sprawność ogólna silnika motosprężarki

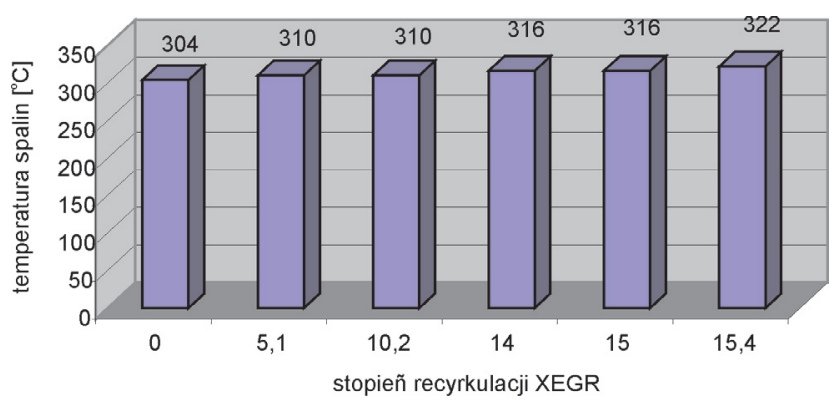

Fig. 22. Influence of EGR on the exhaust gas temperature Rys. 22. Wplyw stopnia recyrkulacji spalin na temperature spalin 


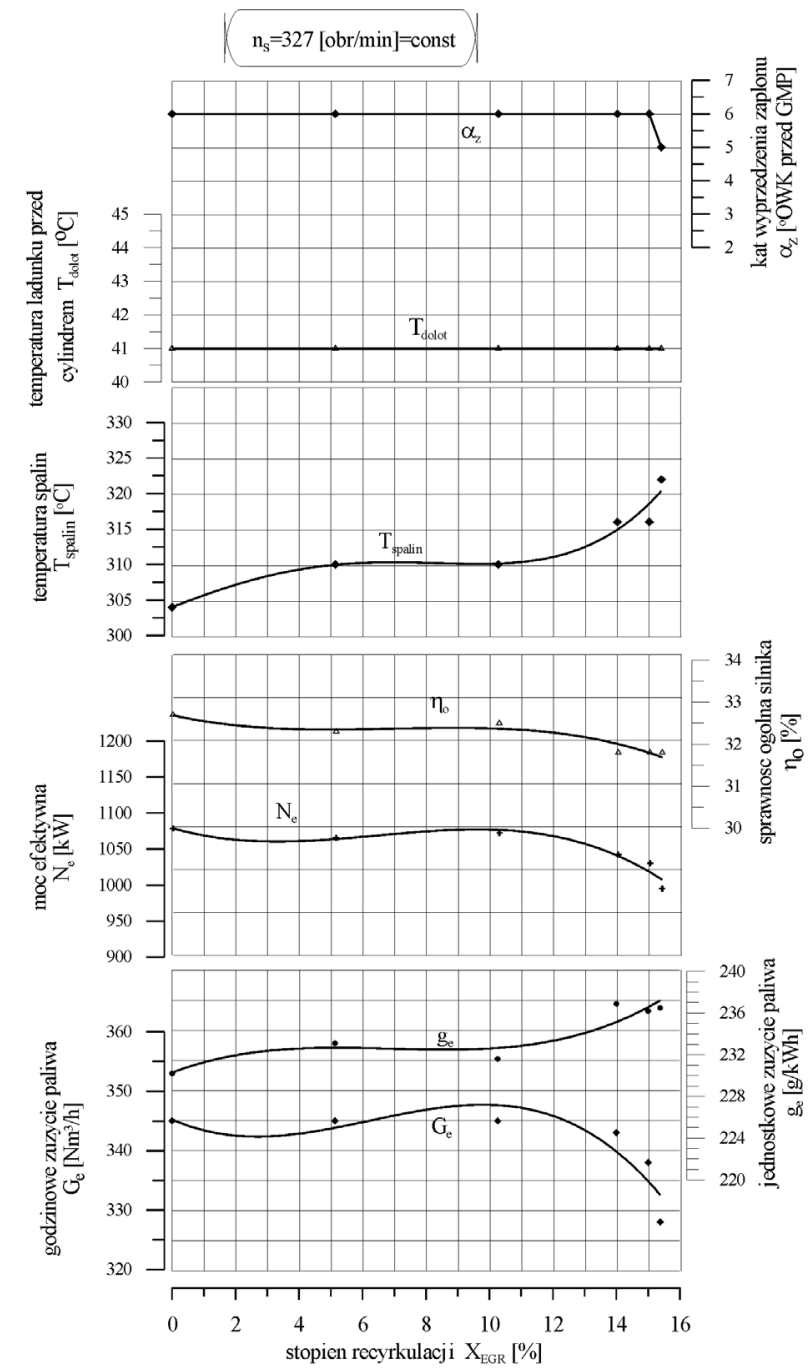

Fig. 23. Influence of exhaust gas recirculation on the overall performance Integral Engine-Compressor

Rys. 23. Wpływ stopnia recyrkulacji spalin na ogólne parametry motosprężarki

3. When the $X_{\mathrm{EGR}}$ value does not exceed $\mathrm{X}_{\mathrm{EGR}}=15 \%$ the general engine efficiency remains constant and equal to $32 \%$. The value of power is sufficient.

Paper reviewed/Artykut recenzowany

Mr. Marek Rudkowski, DEng. - NGV AUTOGAS Sp. z o.o., Cracov, Poland.

Dr inż. Marek Rudkowski - NGV AUTOGAS Sp. z o.o., Kraków, Polska.

e-mail: mrudkowski@ngvautogas.com.pl

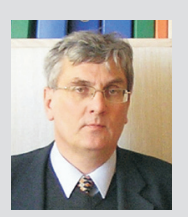

Mr. Sławomir Dudek, DEng. - NGV AUTOGAS Sp. z o.o., Cracov, Poland.

Drinż. Slawomir Dudek-NGVAUTOGAS Sp. z o.o., Kraków, Polska.

e-mail:sdudek@ngvautogas.com.pl

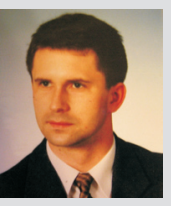

Na rys. 23 możemy prześledzić przebieg omawianych wyżej zależności w formie wykresu. W pozycji pierwszej przedstawiającej przy nominalnej prędkości obrotowej $n_{\mathrm{s}}=$ 327 obr/min zależność kąta wyprzedzenia zapłonu od stopnia recyrkulacji spalin $\mathrm{X}_{\mathrm{EGR}}$ obserwujemy występowanie wyraźnej granicy przy wartości $\alpha=6^{\circ}$.Po przekroczeniu wartości $\mathrm{X}_{\mathrm{EGR}}$ $=15 \%$ pojawia się konieczność opóźnienia kąta wyprzedzenia zapłonu o $1^{\circ}$. Przy stosowanej praktycznie w całym zakresie wartości $6^{\circ}$ przed GMP oznacza to około $16 \%$ zmianę.

Po przekroczeniu wartości $\mathrm{X}_{\mathrm{EGR}}=15 \%$ obserwujemy wyraźne pogorszenie pozostałych parametrów.

\section{Zakończenie}

Przez zastosowanie metody recyrkulacji spalin ograniczono emisję $\mathrm{NO}_{x}$ o $33 \%$.

Silnik motosprężarki pracuje w bardzo wąskim przedziale obciążeń i prędkości obrotowych $\mathrm{n}_{\mathrm{s}}=325-330 \mathrm{obr} / \mathrm{min} \mathrm{co}$ eliminuje potrzebę stosowania skomplikowanych układów dozowania spalin.

1. Docelowy układ recyrkulacji spalin powinien być tak dobrany aby maksymalna wartość współczynnika $\mathrm{X}_{\mathrm{EGR}}$ nie przekraczała $15 \%$ co oznacza około $28 \%$ udział spalin w świeżym ładunku.

2. W warunkach gdy wartość stopnia recyrkulacji spalin nie przekracza $\mathrm{X}_{\mathrm{EGR}}=15 \%$ sprawność ogólna silnika utrzymuje się w granicach $32 \%$ i obserwujemy wystarczający zakres mocy.

3. Po zastosowaniu recyrkulacji spalin osiągnięto zakładane, znaczne ograniczenie emisji tlenków azotu.

\section{Bibliography/Literatura}

[1] Loukanine V., Khatchiyan A., Shislov I., Khamidullin R.: Analysis of Different Ways to Develop Low Emission Natural Gas Engines. NGV2000, 7th International Conference and Exhibition on Natural Gas Vehicles, Yokohama, Japan 2000.

[2] Merkisz J., Kozak M.: Możliwości spełnienia nowych norm toksyczności spalin przez silniki zasilane paliwami gazowymi i konwencjonalnymi. Materiały V Międzynarodowej Konferencji Naukowej SILNIKI GAZOWE 2000. Częstochowa 2000.

[3] Noble D., Beaumont A.: Control System for a Low Emissions Natural Gas Engine for Urban Vehicles. SAE Paper No. 910255.

[4] Nylund N., Riikonen A.: Low Polluting Gas Fuelled HeavyDuty Vehicles. SAE Paper No. 912365.

[5] Saxena M., Mathur H., Radzimirski S.: Reduction of Fresh Charge Losses by Selective Exhaust Gas Recirculation (SEGR) In Two-Stroke Engines. SAE Paper No. 891806.

[6] Teodorczyk A., Przastek J.: Analiza obliczeniowa wpływu recyrkulacji spalin na emisję $\mathrm{NO}_{\mathrm{x}} \mathrm{w}$ silniku o zapłonie iskrowym. Journal of KONES Internal Combustion Engines 1999.

[7] Throop M., Cook J., Hamburg D.: The Effect of EGR System Response Time on NOx Feedgas Emissions during Engine Transient. SAE Paper No. 850133.

Mr Ryszard Wołoszyn, DEng. - doctor in the Faculty of Mechanical Engineering at Radom University of Technology.

Dr inż. Ryszard Woloszyn - adiunkt na Wydziale Mechanicznym Politechniki Radomskiej.

e-mail: rw@prradom.pl 